УДК: 7.036(4)

ББК: 79.1

A43

DOI: $10.18688 /$ aa200-5-65

G. Świtek

\title{
From Historic Inventory to Contemporary Display: The Collections of the Zachęta - National Gallery of Art in Warsaw
}

\section{Introduction}

In 2009 the Zachęta - National Gallery of Art in Warsaw opened an exhibition of its postwar collection of Polish artists, titled To Pee in a Bun: Works from the Collection of ZachętaNational Gallery of Art [12] (Fig. 1). The title was a quotation from one of the classics of Polish conceptual art, Edward Krasiński (1925-2004), renowned for his spatial interventions with the blue scotch. Krasiński's short, scatological poem "Wouldn't it be fun to pee in a bun" was included in his 1997 exhibition catalogue [3] $]^{1}$. In 2009 the gallery invited Karol Radziszewski, a young Polish artist (at that time 29-year-old) to curate the exhibition of the works from the Zachęta's collection. It was the artist-curator who suggested the title, made a subjective selection of artworks and presented an unusual exhibition concept and design.

Radziszewski included the installation by Krasiński which was made for his aforementioned one-man show held at the Zachęta in $1997^{2}$. Nowadays, this project is part of the Zachęta's collection of Polish contemporary art (Fig. 2). Krasiński's installation features full-scale photographic replicas of many paintings which were found in the Zachęta's collection before World War I and II, such as Jan Matejko's Battle of Grunwald (Battle of Tannenberg, 1878) - the icon of Polish historicist painting of the late $19^{\text {th }}$ century. Krasiński's work of 1997 was a conceptual game of appropriation played with the Zachęta's historical masterpieces; most of them, including Matejko's Battle of Grunwald, are now on display in the National Museum in Warsaw. Krasiński's blue scotch - "Blue plastic Scotch Tape; the width of $19 \mathrm{~mm}$, length unknown. I stick it everywhere and on everything, horizontally at the height of $130 \mathrm{~cm}^{\prime \prime 3}$ - clasped the paintings' replicas together, creating one artwork, i.e. one art exhibition. In this sense, Krasiński's 1997 installation can be named the artist-curated exhibition of the Zachęta's prewar collection, falling within the history of the "artists as curators", or the history of the artistcreated collections, and marked with the gestures of choosing, similar to those by Marcel Duchamp (La Boîte-en-Valise, first version 1941) and Marcel Broodthaers (Musée d'Art Moderne, Department des Aigles, 1968-1972) [6; 4, p. 332].

On Krasiński's scatological limericks see also: [11, p. 287].

See the photographs of Edward Krasiński's exhibition at the Zachęta Gallery of Art, Warsaw (28.0401.06.1997), in: [3]. For Krasiński’s interventions in the Zachęta’s exhibition halls in 1997, see also: [20, pp. 152-154]. See Krasiński E. Intervention, exhibition catalogue. Pawilon Gallery, 1976. Cited in: [19, p. 34]. 


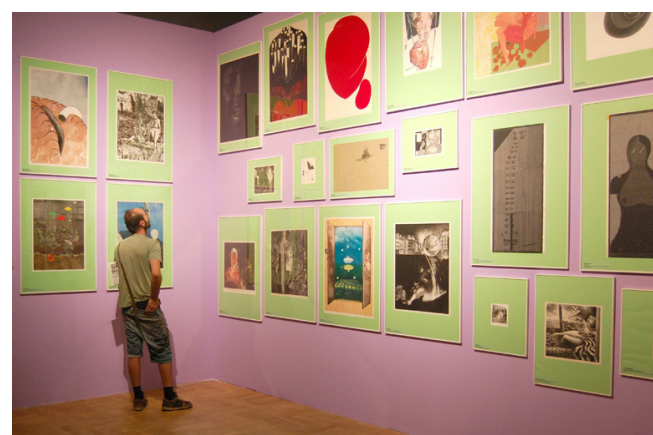

Fig. 1. To Pee in a Bun: Works from the Collection of Zachęta - National Gallery of Art (2009), exhibition view. Photo: Zachęta — National Gallery of Art, Warsaw

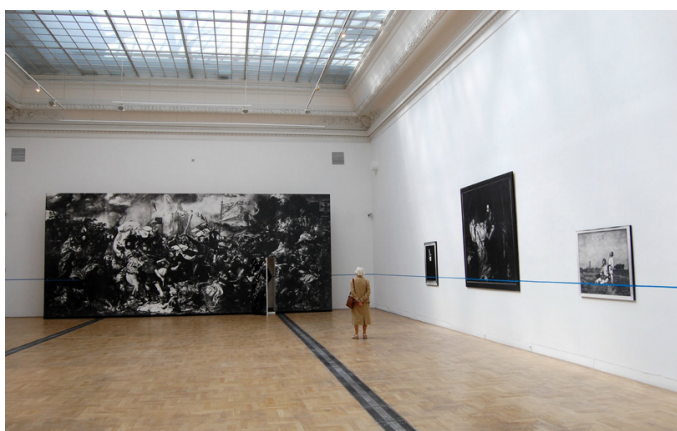

Fig. 2. To Pee in a Bun: Works from the Collection of Zachęta - National Gallery of Art (2009), exhibition view, Edward Krasiński's installation of 1997 (in the background: a photographic replica of Jan Matejko's Battle of Grunwald, 1878). Photo: Zachęta - National Gallery of Art, Warsaw

Inspired by Krasiński's quasi-curatorial act, Radziszewski considered the conceptual artist a spiritual patron of his 2009 exhibition. But Radziszewski's idea was not only to replace the blue scotch with Scotch Pink, his own artistic and subversive signature, but also to challenge the dominant museum strategy of presenting "masterpieces from the collection". "Curators try to showcase the pearls of their collections" - Radziszewski argued - "I decided to go with unusual works and artists whose names are largely unknown"4. It is not an accident that I choose the exhibition To Pee in a Bun as an example opening my comments on the status of the Zachęta's collections, created in different periods of time by three different institutions, and on our contemporary strategies of display. The 2009 exhibition alluded to three types of collections that are associated today with the name of Zachęta - National Gallery of Art.

\section{Zachęta's First Collection}

Following chronology, the first type is a historical collection of Polish art that was amassed in Warsaw prior to the I World War by the Society for the Encouragement of the Fine Arts. As a citizen initiative, the society was founded in 1860 in the Russian partition of Poland. It was dissolved just after the World War II and its collection was divided amongst different departments of the National Museum in Warsaw [10; 17, p. 359]. Today gallery's function is primarily as a place of temporary exhibitions; Zachęta - National Gallery of Art does not present its collections on permanent display.

Some traces of the first permanent, national collection - created at the time when Poland did not exist as an independent state and at the parallel time of formation of nation-states which affected the proliferation of museums in Western Europe [8; 17, p. 273] - are still preserved in the very name of the institution. "Zachęta" means "encouragement" in Polish; this word alludes to the name of the pre-war Society for the Encouragement of the Fine Arts, the

4 From A to C and Back Again: A Conversation between a Young Artist and the Curator of the Exhibition, in: $[12$, p. 3$]$. 


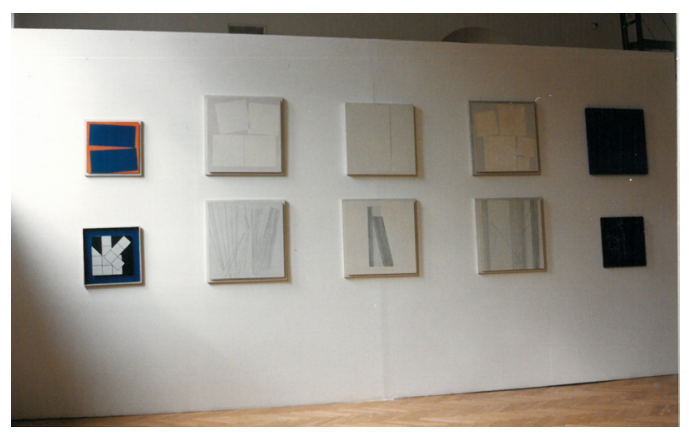

Fig. 3. A Fragment of the Collection 2 (1995), exhibition view with the works by Henryk Stażewski. Photo: Zachęta - National Gallery of Art, Warsaw

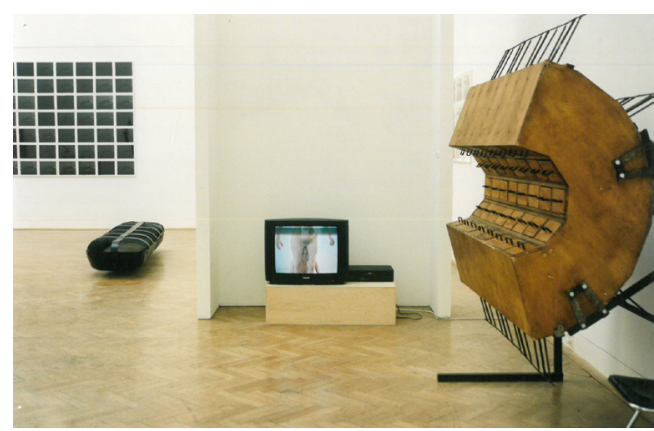

Fig. 4. A Fragment of the Collection 3 (1998), exhibition view with Artur Żmijewski's 40 Drawers (1995) in the foreground. Photo: Zachęta - National Gallery of Art, Warsaw

founder of both the collection and the gallery's building, erected in 1900 in Warsaw. Moreover, the Zachęta's largest exhibition hall is still named after Jan Matejko. His aforementioned Battle of Grunwald was on permanent display in this hall during the interwar period.

Thus, Krasiński's conceptual intervention of 1997 - recalled by Radziszewski in 2009 created a "hauntological" situation (in a Derridian understanding of something that is contradictory in appearance and calls for our re-interpretation of its visible-invisible body [5, pp. 156-160]). Krasiński presented the photographic re-enactment of the original museumlike space of the Zachęta which exists today only as an exhibition hall with no original $19^{\text {th }}$ century paintings. Radziszewski re-created this re-enactment in his own curatorial project.

\section{Zachęta's Second Collection}

The second type of the collection associated today with the Zachęta - National Gallery of Art in Warsaw is the one that was accumulated between 1949 and 1992, that is during the period of existence of the Central Bureau for Artistic Exhibitions. The Central Bureau was located in the building erected in 1900 by the Society for the Encouragement of the Fine Arts, badly damaged during the Warsaw Uprising in 1944 and restored after the II World War [15; 17, p. 357]. The activities of the Central Bureau were fully subject to the political and economic control of the Ministry of Culture and Art. The statutory responsibilities of this central institution were generally defined as the popularisation of art and the organisation of artistic life over the whole territory of the Polish People's Republic (1947-1989), including: "the purchasing of works of art" from contemporary artists, "the negotiations of the sale of works of art shown at exhibitions organized by the Bureau", "the inventory [...] of works of contemporary art ordered by the Ministry" [9; 17, p. 359].

The Central Bureau accumulated works of art in the Zachęta's gallery building, but without any overall conception of a permanent collection of Polish contemporary art. The purchases were often selected on grounds which had nothing to do with a clearly defined artistic profile. Works were bought from exhibitions (i.e. solo exhibitions of Polish artists presented at Zachęta, or the group exhibitions of the members of the Union of Polish Artists), competitions and sometimes simply as an official form of financial aid to artists. The funds for pur- 
chase came from the Ministry of Culture and Art: from the Fund for the Development of the Visual Arts, or through the national ordering system of the Art Department in the Ministry $[14 ; 17$, p. 365].

In the 1960s and 1970s the Central Bureau for Artistic Exhibitions located in the Zachęta's building became something of a transitory staging post for purchases ordered by the Ministry and their subsequent distribution amongst other institutions, such as state museums, public buildings, or the headquarters of the Polish People's Army (the latter example is connected with the exhibitions celebrating the anniversaries of the Polish People's Army, held regularly at Zachęta in 1963, 1968, 1973 and 1978 ${ }^{5}$ ). Briefly speaking, the post-war collection of the Zachęta - the gallery of the Central Bureau for Artistic Exhibitions, until the dissolution of this institution at the time of political transformation of the state after 1989 - is a bizarre conglomerate mirroring the meanders of official cultural policy of the Polish People's Republic.

In this sense, the 2009 exhibition To Pee in a Bun was conceived as a provocative display of an "unwanted heritage" [13]. Radziszewski's curatorial experiment included paintings and rarely displayed graphic works, mainly dating back to the 1960s and 1970s. As we recall, the artistcurator intended to challenge the strategy of presenting masterpieces from the collection. As a consequence, he focused on the seldom, or never, shown "storeroom mass". Moreover, Radziszewski claimed that he was embodying a curator as an "unfulfilled artist." As he argued: "Curators are the ones who [...] manipulate the works being displayed, creating their own narratives from pre-existing works, at the same time disregarding their previous context"6. $\mathrm{He}$ also admitted: "I treated other artists works as elements of a larger whole, like tubes of paint, from which I have to squeeze out colours in order to paint one complex painting. [...] I created the exhibition as if I were planning a giant picture - relying most on intuition"7. Thus, the artist's concept resulted with a very aesthetic whole, composed of some works of questionable artistic values, to put it mildly. In one of the exhibition halls, for example, the paintings, placed against a colourful background, were mounted from the largest to the smallest irrespectively of their chronology order or their iconography. As the artist-curator explained: "it was the easiest way to organize them"s.

On the one hand, the exhibition To Pee in a Bun was appreciated for implementing the strategy of artist-as-curator. ${ }^{9}$. Under the mask of irony - not quite accepted by the artists whose works were presented - the viewers could discover the important issues tackled by this exhibition. Indeed, it embraced the issue of working with the historical collection, and the question of the official art production as a result of the cultural policy of the Polish People's Republic. On the other hand, this experiment provoked strong criticism, directed both against the artist and the gallery. Radziszewski was criticised, for example, for acting in an "unceremonious manner" as a curator, or for treating artworks as purely visual objects as if there were no social, economic and political history behind them [13].

See Galeria Zachęta. Kalendarium wystaw 1950-2000, in: [17, pp. 332-336].

From A to C and Back Again [12, p. 2].

Ibidem, [12, pp. 2-3].

Ibidem, [12, p. 8].

For the concept of artists-as-curator see for example: [4; 17, pp. 329-346]. 


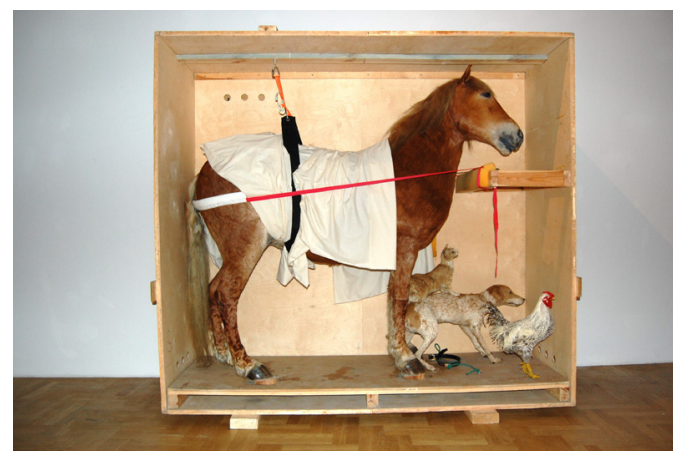

Fig. 5. This Is Not an Exhibition (2008), exhibition view with Katarzyna Kozyra's Pyramid of Animals (1993). Photo: Zachęta - National Gallery of Art, Warsaw

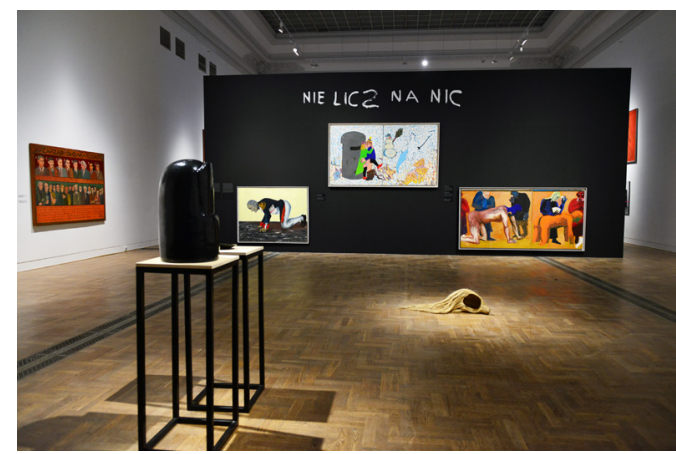

Fig. 6. Collections (2016), exhibition view. Photo: Zachęta - National Gallery of Art, Warsaw

\section{Zachęta's Third Collection}

Let us now elaborate on the third type of collection amassed in the Zachęta - National Gallery of Art. Radziszewski's exhibition, as we recall, included one of the most spectacular projects by Edward Krasiński, which had been produced especially for his exhibition held at Zachęta in 1997 (Fig. 2). This installation may also be considered a symbol of the new opening in what concerns collecting Polish contemporary art. The history of Zachęta's collection took a new turn in 1992 when the Central Bureau for Artistic Exhibitions was disbanded and the building housed a new institution, the Zachęta State Gallery of Art, later renamed: National Gallery of Art. However, one of the statutory requirements of Zachęta nonetheless remains "the collection, inventory and upkeep of works of contemporary art" [16; 17, p. 362].

In 2018 Zachęta's current collection numbers 3,598 works: 709 paintings, 97 sculptures, 31 installations, 2,107 prints, 313 drawings, 236 photographs and 236 videos, including 163 deposits ${ }^{10}$. These data include the works bought by the Central Bureau for Artistic Exhibitions (the collection uneven from an artistic perspective but intriguing from a political one) as well as the most recent acquisitions. Except for 57 works by foreign artists, it is a collection of Polish contemporary art (despite the gallery's international programme). The works document a number of important phenomena in Polish art from the late 1940s until today, including different types of geometric abstraction, the metaphorical-expressive movement (a Polish version of surrealist tendencies in modern art), the new figurative movement of the 1980s, and the most recent tendencies, such as the so-called "critical art" of the 1990s. During the 1990s and at the beginning of the $21^{\text {st }}$ century the Zachęta has succeeded in putting together a collection of works by middle generation and young generation of Polish artists, such as, internationally renowned Paweł Althamer (b. 1967), Mirosław Bałka (b. 1958), Katarzyna Kozyra (b. 1963), Zbigniew Libera (b. 1959) and Artur Żmijewski (b. 1966). The most recent acquisitions are primarily of works by Polish contemporary artists exhibited at the gallery and 
of works co-produced by the Zachęta, whether in-house or for the Polish Pavilion at the Venice Biennale. Today's collection is small yet quite mobile. In 2017, for example, 101 works were on loan in Poland and abroad. One of the most renowned works in the collection, Alina Szapocznikow's sculpture Tumours personified (1971) travelled to KUMU Art Museum in Tallin and to the Hepworth Wakefield art museum, for the first UK retrospective of Szapocznikow, entitled Human Landscapes (21.10.2017-28.01.2018) ${ }^{11}$.

\section{Zachęta's Fragments of the Collection}

The Zachęta - National Gallery of Art does not have a permanent exposition but organises cyclical presentations of its collection, initiated in the 1990s, when the director of the gallery was Anda Rottenberg (1993-2001). In 1994 the Zachęta's storage rooms were being reorganized; as a result, a part of the painting collection was presented. The exhibition was titled A Fragment of the Collection and included about 100 works by 42 artists, such as Tadeusz Kantor (1915-1990) or Stefan Gierowski (b. 1925). A year later the Zachęta gallery presented A Fragment of the Collection 2 (Fig. 3), with a selection of works from the constructivist and geometric movement, acquired already by the Central Bureau for Artistic Exhibitions. During the 1970s, the gallery obtained, for example, a large and valuable collection of the paintings by Henryk Stażewski (1894-1988), one of the most renowned Polish avant-garde artists representative of geometric abstraction. The third Fragment of the Collection (Fig. 4) was shown in 1998. It included works gathered in the years 1980-1990 which were mostly either donated or deposited by the artists. Katarzyna Kozyra's celebrated Pyramid of Animals (1993) was shown in A Fragment of the Collection 3, as well as Artur Żmijewski's diploma work 40 Drawers (1995).

Kozyra's Pyramid of Animals, amongst other works, was also shown ten years later, in a different display context. In 2008 the Zachęta organized another presentation of its collection titled This Is Not an Exhibition, which was in fact the exhibition evolving around a theme of collection care $^{12}$. One of the exhibition spaces was arranged to look like a museum storage room. The curators from the Department of Collection and Inventories have gathered collection items in the same manner in which they are usually stored — in crates, on racks (Fig. 5). The second room became a place of working with objects such as complex-assembly installations, large-format works difficult to store and transport, or objects presenting conservation problems - it is worth emphasising that the Zachęta gallery has no conservation department; most major works are commissioned in other institutions. The viewers responded to the project This Is Not an Exhibition with enthusiasm, because they could observe these activities, taking part in meetings with artists who were invited to discuss their technique and material aspects of their work. At the same time, the curators of the collection had an opportunity to take photographs of large-format items and to film the assembly of works.

Collection building is a significant part of the Zachęta gallery's contemporary mission, however, it is not the institution's main activity. The number of annual acquisitions varies depend-

11 Raport Roczny 2017, p. 125. See also: https://hepworthwakefield.org/whats-on/alina-szapocznikowhuman-landscapes/ (accessed 10 December 2018).

12 To nie jest wystawa / This Is Not an Exhibition, Zachęta - National Gallery of Art, Warsaw (26.024.05.2008), https://zacheta.art.pl/pl/wystawy/to-nie-jest-wystawa? (accessed 10 December 2018). 
ing on funds obtained through the Ministry of Culture and National Heritage programme Collections - Regional Collections of Contemporary Art, funds offered by sponsors and generated by crowdfunding. The 2016 presentation of a fragment of the Zachęta's collection, with a simple title Collections (Fig. 6), was dedicated mainly to the gallery's sponsors ${ }^{13}$. The 2016 acquisitions - e. g. the works by Anna Jermolaewa (b. 1970), Wojciech Gilewicz (b. 1974), Karol Radziszewski (b. 1980), Iza Tarasewicz (b. 1981) and Monika Zawadzki (b. 1977) were presented in the context of works which has been in the Zachęta's deposit for years, such as the paintings by Edward Dwurnik (1943-2018). The plural noun - Collections - alluded to another important Polish collection of contemporary art, i.e. the Arsenał Gallery in Białystok, which participated in the exhibition. The collection from Białystok, like the one from the Zachęta, reflects the exhibition programme of the institution; it includes a strong representation of East and Central European art with a special focus on the art from Ukraine, Belarus, Georgia and Moldova.

In November 2018 another exhibition of a fragment of the collection was open at the Zachęta gallery, titled Very Diverse and Very Exquisite: Graphic Works from the Collection of Zachęta ${ }^{14}$. The curators from the Department of Collections and Inventories presented a selection of the 2,107 prints amassed in the gallery since the 1950s, which reflects exhibition programme of the Central Bureau for Artistic Exhibitions. Many successful graphic art exhibitions took place in the Zachęta gallery during the period of $\mathrm{CBAE}$, including national exhibition, anniversary exhibitions as well as individual shows; the $1^{\text {st }}$ National Exhibition of Graphic Arts and Drawing (1956), Polish Exhibition of Graphic Works (1967) or the Graphic Arts in the Polish People's Republic (1971) are cases in point. The curators' intention was to re-define the historical context of the medium. On the one hand, graphic works are the most numerous items in the Zachęta's collection; they also occupied an important position in the hierarchy of the visual arts in the 1950s, 1960s and 1970s. On the other hand, they are the least known works in the gallery's collection and have been gradually marginalised as a genre over the last three decades.

A decision to present - once again - part of the Central Bureau's collection coincided with an academic research project which was carried out in the years 2014-2018 at the Zachęta in cooperation with the Institute of Art History at the University of Warsaw. The project titled History of Exhibitions at the Zachęta - Central Bureau for Artistic Exhibitions in 1949-1970 included the examination of selected exhibitions held at the Zachęta, grouped in thematic blocks which define the main directions of the exhibition policy of the institution [21]. The history of exhibitions organized by the gallery is closely interconnected with the profile of the Zachęta's collection. As was already mentioned, during the period of existence of the Central Bureau artworks were often bought from the exhibitions held in the

13 Kolekcje/Collections, Zachęta - National Gallery of Art, Warsaw (5.12.2016-1.01.2017), https:// zacheta.art.pl/en/wystawy/kolekcje?setlang=1 (accessed 10 December 2018).

${ }_{14} \quad$ Bardzo różnie i bardzo dobrze. Grafiki z kolekcji Zachęty/Very Diverse and Very Exquisite: Graphic Works from the Collection of Zachęta, Zachęta - National Gallery of Art, Warsaw (9.11.2018-20.01.2019)/ Available at: https://zacheta.art.pl/en/wystawy/bardzo-roznie-i-bardzo-dobrze-grafiki-z-kolekcji-zachety?setlang=1 (accessed 10 December 2018). See also: "Very Diverse and Very Exquisite": Graphics from the Collection of Zachęta, in: Karaszewska D.; Jurkiewicz M.; Miś M.; Pieńkos J. (eds.). Zachęta: September, October, November, December 2018. Warsaw, Zachęta - National Gallery of Art Publ., 2018, pp. 44-49. 
gallery. Once more, the history of the institution - which mirrors the meanders of Polish cultural policy - becomes an important point of reference for the current presentation of the Zachęta gallery's collection.

\section{Conclusion}

As concluding remarks, let us return to the 2009 exhibition To Pee in a Bun: Works from the Collection of Zachęta - National Gallery of Art (Fig. 1-2). The most provocative of all contemporary displays of the Zachęta's collection, the show stirred the Polish art milieu to discuss the current status and the future of the collections of contemporary art. In the course of this discussion some important questions were raised, and they are still valid for the institution's policy - as the 2016 exhibition Collections, or the 2018 exhibition Very Diverse and Very Exquisite: Graphic Works from the Collection of Zachęta clearly demonstrate.

How could we present today the official art production typical for the times of the Polish People's Republic, especially the one which does not fall within a category of the avant-gardes? How did the processes of artistic production, distribution and public presentation look like during that period - given the fact that they affected collection building? And how could these processes be represented today within a framework of a collection exhibition? How could we find a balance between the subversive strategy of "artist-as-curator" and the more traditional ways of presenting artworks from the gallery's collection, based on art historical research? How could we negotiate between the museum strategy of presenting "masterpieces from the collection" (or the "most recent acquisitions", "new works") and the current fascination with the history of exhibitions and political aspects of Zachęta's historical collections while accepting the argument that "the history of exhibitions is a history of politics"? ${ }^{15}$ Hopefully, not only the theories of new museology, but also the gallery's exhibition practice will bring us some refreshing answers.

\section{References}

1. Bagińska A. (ed.). The Space of Creation in Art and Art History. Warsaw, Institute of Art History, University of Warsaw Publ., 2015. 156 p.

2. Beck M. The Exhibition and the Display (2009). Steeds L. (ed.). Exhibition. London; Cambridge MA, Whitechapel Gallery, The MIT Press Publ., 2014, pp. 27-32.

3. Chrzanowska-Pieńkos J.; Kardasz M. (eds.). "Coś mnie korci, żeby zrobić siusiu w torcik”("I Am Tempted to Pee in the Birthday Cake"). Edward Krasiński, Exhibition Catalogue. Warszawa, Galeria Zachęta Publ., 1998 , not paginated.

4. Corrin L. G. Mining the Museum: Artists Look at Museums, Museums Look at Themselves. Carbonell B. M. (ed.). Museum Studies: An Anthology of Contexts. Chichester, Wiley-Blackwell Publ., 2012, pp. 329-346.

5. Derrida J. Spectres of Marx: The State of the Debt, the Work of Mourning and the New International. New York; London, Routledge Publ., 1994. 258 p.

6. Filipovic E. When Exhibitions Become Form: On the History of the Artist as Curator (2013). Steeds L. (ed.). Exhibition. London; Cambridge MA, Whitechapel Gallery, The MIT Press Publ., 2014, pp. 158-159.

7. Lohse R. P. Neue Ausstellungsgestaltung / Nouvelles conception de l'exposition / New Design in Exhibitions. Erlenbach, Verlag für Architektur Publ., 1953. 260 p. 
8. Macdonald Sharon J. Museums, National, Postnational and Transcultural Identities. Museum and Society, 2013, vol. 1, no. 1, pp. 1-16.

9. Mansfeld J. The Central Bureau for Artistic Exhibitions. Zachęta 1860-2000. Świtek G. (ed.). Warszawa, Zachęta Narodowa Galeria Sztuki Publ., 2003, pp. 179-182.

10. Morawińska A. The Collections of the Society for the Encouragement of the Fine Arts. Switek G. (ed.). Zachęta 1860-2000. Warszawa, Zachęta Narodowa Galeria Sztuki Publ., 2003, pp. 62-64.

11. Nader L. The Heterology of the Blue Line. Switek G. (ed.). Awangarda w bloku / Avant-garde in the Bloc. Warszawa, Fundacja Galerii Foksal Publ., 2009, pp. 282-293.

12. Radziszewski K. (ed.). To Pee in a Bun: Works from the Collection of Zachęta National Gallery of Art / Siusiu w torcik. Prace ze zbiorów Zachęty Narodowej Galerii Sztuki (5.09-22.11.2009), booklet. Warsaw, Zachęta National Gallery of Art Publ., 2009. 8 p.

13. Sienkiewicz K. Zachęta $w$ posadach drży. Available at: https://www.dwutygodnik.com/artykul/496zacheta-w-posadach-drzy.html (accessed 29 September 2018).

14. Stepnowska T. A. Gallery Zachęta’s Contemporary Collections. Świtek G. (ed.). Zachęta 1860-2000. Warszawa, Zachęta Narodowa Galeria Sztuki Publ., 2003, pp. 205-237.

15. Świtek G. The History of the Zachęta Building 1860-1945. Świtek G. (ed.). Zachęta 1860-2000. Warszawa, Zachęta Narodowa Galeria Sztuki Publ., 2003, pp. 48-49 (in Polish).

16. Świtek G. Zachęta State Gallery of Art. Świtek G. (ed.). Zachęta 1860-2000. Warszawa, Zachęta Narodowa Galeria Sztuki Publ., 2003, pp. 186-190 (in Polish).

17. Świtek G. (ed.). Zachęta 1860-2000. Warszawa, Zachęta Narodowa Galeria Sztuki Publ., 2003. 381 p. (in Polish).

18. Świtek G. Od Simmlera do Althamera. Folga-Januszewska D. (ed.). Nowe muzeum sztuki współczesnej czy nowoczesnej? Warszawa, Krajowy Ośrodek Badań i Dokumentacji Zabytków Publ., 2005, pp. 177184 (in Polish).

19. Świtek G. (ed.). Awangarda w bloku / Avant-garde in the Bloc. Warszawa, Fundacja Galerii Foksal Publ., 2009. 496 p. (in Polish and English).

20. Switek G. The Horizon of Touch: Edward Krasiński’s Blue Tape in the Space of the Artist's Studio. Bagińska A. (ed.). The Space of Creation in Art and Art History. Warsaw, Institute of Art History, University of Warsaw Publ., 2015, pp. 144-156.

21. Świtek G. The History of Exhibitions at Zachęta - Central Bureau of Artistic Exhibitions in 1949-1970. Zachęta: September, October, November, December, 2018, pp. 66-74.

Title. From Historic Inventory to Contemporary Display: The Collection of the Zachęta - National Gallery of Art in Warsaw

Author. Gabriela Świtek - dr. habil., chair of art theory. Institute of Art History, University of Warsaw, ul. Krakowskie Przedmieście 26/28 00-927 Warsaw, Poland; director plenipotentiary for scientific affairs. Zachęta - National Gallery of Art in Warsaw, pl. Małachowskiego 3, 00-916 Warsaw, Poland. ihs@uw.edu.pl

Abstract. The history of the post-war collection of the Zachęta - National Gallery of Art in Warsaw is one of meanders of Polish cultural policy. Today gallery's function is primarily as a place of exhibition (Kunsthalle). The collection of Polish art that was amassed here prior to the II World War now constitutes a substantial element in the inventories of the National Museum in Warsaw. However, one of the statutory requirements of Zachęta nonetheless remains "the collection, inventory and storage of contemporary works of art". Zachęta's current collection numbers 3598 works (Annual Report 2017). The works document a number of important phenomena in Polish art from the late 1940s until today, including different types of geometric abstraction, the metaphorical-expressive movement (a Polish version of surrealist tendencies), the new figurative movement, the Polish Colourist aesthetics, and the most recent tendencies, such as the so-called "critical art" of the 19902000s. In 1949 the Central Office for Art Exhibitions was founded and located in the Zachęta building. The collection accumulated during the Central Office for Art Exhibitions period of existence (until 1992) is not one that had a well-defined profile. Works were bought from exhibitions, competitions and sometimes simply as a form of aid to artists. The funds for purchase came from the Ministry of Culture and Art: from the Fund for the Development of the Visual Arts, or through the national ordering system of the Art Department in the Ministry. However, during the 1970s, works began to be acquired for the purposes of exhibitions and education. The most recent acquisitions are primarily of works by Polish contemporary artists exhibited at the gallery and of works co-produced by the Zachęta, whether inhouse or elsewhere (e.g. for the Polish Pavilion at the Venice Biennale). During the 1990-2000s the Zachęta has succeeded in putting together a collection of 
works by middle generation and young generation of Polish artists (such as, internationally renowned Paweł Athamer, Mirosław Bałka, Katarzyna Kozyra, Zbigniew Libera and Artur Żmijewski). Collection building is a significant part of the gallery's contemporary policy. This is made possible by funds offered by sponsors (such as the ING Polish Art Foundation), funds obtained through the Ministry of Culture and National Heritage programme Collections - Regional Collections of Contemporary Art, and also funds generated by Zachęta specially for the purpose or donations of works by artists (crowdfunding). Works from the collection are also included in the Zachęta's exhibition and educational programme. The focus of the paper is on the transition from the Zachęta's historical inventories to the issues of collection's contemporary forms of display.

Keywords: Zachęta, Polish art history, contemporary art

Название статьи. От запасников к современной выставке: коллекция Национальной галереи искусств Захента в Варшаве

Сведения об авторе. Щвитек Габриэла - dr. habil., заведующая кафедрой теории искусства. Институт истории искусства, Варшавский университет. ул. Краковские Пржедмиесщие 26/28 00-927, Варшава, Польша; начальник отдела документации. Национальная галерея искусств Захента, пл. Малаховскиего 3, 00-916, Варшава, Польша. ihs@uw.edu.pl

Аннотация. История коллекции послевоенного искусства Национальной галереи искусств Захента отражает все перипетии культурной политики Польши. В настоящее время галерея главным образом выполняет функцию выставочного пространства. Коллекция польского искусства, собранная здесь до Второй мировой войны, сейчас занимает видное место в фондах Национального музея в Варшаве. Вместе с тем одной из прописанных в уставе обязанностей Захенты остаётся «коллекционирование, инвентаризация и хранение объектов современного искусства». По данным ежегодного отчёта Захенты (2017), её собрание насчитывает 3598 произведений. Эти работы отражают многие важные явления в польском искусстве с конца 1940-х гг. по сей день, включая различные типы геометрической абстракции, метафорико-экспрессивное движение (польская вариация сюрреалистических тенденций), новое фигуративное течение, эстетику «польских колористов», а также новейшие тренды, в том числе так называемое «критическое искусство» 1990-2000-х гг. В 1949 г. в здании Захенты было основано Центральное управление художественными выставками. Коллекция, собранная в годы работы Управления (до 1992 г.), не отличается последовательным подходом. Работы приобретались на выставках, конкурсах, а иногда и просто в качестве помощи художникам. Средства на покупку выделялись Министерством культуры и искусства Польши: из Фонда развития визуальных форм искусства или через систему госзаказов. С 1970-х гг. работы начали приобретаться для выставок с просветительскими целями. Последние покупки музея - главным образом работы современных польских художников, выставляемые в галерее, а также произведения, созданные при участии Захенты как для собственных, так и для внешних проектов (например, для Польского павильона на Венецианской биеннале). В 1990-2010 гг. Захенте удалось собрать коллекцию работ молодого и среднего поколений польских художников, включая таких всемирно признанных авторов, как П. Альтхамер, М. Балка, К. Козыра, 3. Либера и А. Жмиевский. Пополнение коллекции составляет важную часть текущей политики галереи. Её осуществление стало возможным благодаря спонсорам (например, фондy ING Polish Art Foundation), финансированию от Министерства культуры и программы сохранения национального наследия «Коллекции - региональные собрания современного искусства», а также за счёт средств, собранных самой галереей, и работ, переданных в дар художниками (краудфандинг). Предметы искусства из этой коллекции тоже включены в экспозиционную и образовательную программу Захенты. В статье рассматривается история коллекционирования музея в контексте вопросов современного экспонирования.

Ключевые слова: Захента, искусство Польши, современное искусство, формирование коллекции 